however, between raised serum concentrations of $\delta$ aminolaevulinic acid and neurodysfunction. All four types of acute porphyria, in which concentrations of $\delta$ aminolaevulinic acid are raised, are characterised by neurological dysfunction whereas the non-acute porphyrias, which have normal concentrations of $\delta$ aminolaevulinic acid, are not. Furthermore, peripheral neuropathy is a feature of lead poisoning and hereditary tyrosinaemia, in which blood concentrations of $\delta$ aminolaevulinic acid are raised.

Intravenous infusion of haematin, which represses activity of $\delta$ aminolaevulinic acid synthase and hence lowers the increased blood concentrations of $\delta$ aminolaevulinic acid and porphobilinogen, provides some benefit in acute porphyria. ${ }^{5}$ Tishler et $a l^{12}$ reported that activated charcoal cartridges effectively removed large amounts of porphyrins and their precursors from solution in vitro, these amounts being considerably greater than estimated daily production during an attack of porphyria. The removal of $\delta$ aminolaevulinic acid and porphobilinogen and possibly other neurotoxic compounds by haemoperfusion through such sorbents might favourably alter the course of acute attacks.

In our study haemoperfusion with activated charcoal columns coupled with haemodialysis considerably reduced serum concentrations of $\delta$ aminolaevulinic acid and porphobilinogen with a concomitant decrease in urinary porphyrin precursors; but serum concentrations had returned to pretreatment values within 24 hours and abdominal pain was not relieved after four days' treatment. We cannot exclude the possibility that a longer course of treatment might have had a more favourable outcome, but this seems unlikely in view of the rapid rebound of serum concentrations of $\delta$ aminolaevulinic acid after each haemoperfusion. Furthermore, the resulting thrombocytopenia might present a major limiting factor to such treatment.

We thank Professor Sir Abraham Goldberg for his guidance.

\section{References}

1 Tishler PV, Gordon BJ, O'Connor JA. The absorption of porphyrins and porphyrin precursors by sorbents: a potential therapy for the porphyrias. Methods Find Exp Clin Pharmacol 1982;4:125-31.

2 Tishler PV, Gordon BJ. Sorbent therapy of the porphyrias. II. Experimental plasma or hemoperfusion with a commercial charcoal cartridge. Methods Find Exp Clin Pharmacol 1983;5:185-92.

3 Laiwah ACY, Goldberg A, Moore MR. Pathogenesis and treatment of acute intermittent porphyria: discussion paper. $\mathcal{f} R$ Soc Med 1983; 76:386-92.

4 Winchester JF, Ratcliffe JG, Carlyle E, Kennedy AC. Solute, amino acid, and hormone changes with coated charcoal hemoperfusion in uremia. Kidney Int 1978;14:74-81.

${ }^{5}$ McColl KEL, Moore MR, Thompson GG, Goldberg A. Treatment with haematin in acute hepatic porphyria. $Q \mathcal{F}$ Med 1981;50:161-74.

(Accepted 14 September 1983)

\title{
Complement activation during cardiopulmonary bypass: quantitative study of effects of methylprednisolone and pulsatile flow
}

\author{
MICHAEL J BOSCOE, VIRGINIA M A YEWDALL, MICHAEL A THOMPSON, \\ J STEWART CAMERON
}

\begin{abstract}
Forty four patients undergoing open heart surgery were divided into three groups. Group 1 (17 patients) underwent routine anaesthesia and surgery; group 2 (17 patients) received two doses of methylprednisolone (30 $\mathrm{mg} / \mathrm{kg}$ ), one during induction of anaesthesia and the other immediately before induction of cardiopulmonary bypass; and group 3 (10 patients) received pulsatile flow while undergoing pulsatile perfusion by the heart-lung machine. A modification of the previously described technique was used to detect and measure complement activation in plasma before and during the bypass period using crossed immunoelectrophoresis. About $45 \%$ of all patients showed measurable complement activation $(>4.5 \%)$ during cardiopulmonary by-
\end{abstract}

Department of Anaesthetics, Guy's Hospital, London SE1 9RT MICHAEL J BOSCOE, FFARCS, senior registrar MICHAEL A THOMPSON, MRCP, FFARCS, consultant

Department of Renal Medicine, Guy's Hospital Medical School, London

VIRGINIA M A YEWDALL, AIMLS, medical laboratory scientific officer J STEWART CAMERON, MD, FRCP, professor

Correspondence and requests for reprints to: $\operatorname{Dr} M \mathrm{~J}$ Boscoe. pass and the mean activation in this group was $6.4 \%$. There was no significant difference between the three groups in complement activation. In group 2, however, women showed significantly more complement activation than men $(\mathbf{p}<0.05)$.

It is suggested that neither corticosteroids nor pulsatile flow affect complement activation, but caution should be exercised in women receiving methylprednisolone.

\section{Introduction}

Cardiopulmonary bypass is thought to activate complement. ${ }^{12}$ The importance of this lies in the postoperative changes seen in lung function ${ }^{13}$ and possibly in changes in myocardial function. ${ }^{45}$ Attempts have been made to measure complement activation by changes in haemolytic activity $\left(\mathrm{CH}_{50}\right), 2$ ? by aggregation of white cell polymorphs by activated complement components $^{8}$ and by measurement of absolute concentrations of complement. ${ }^{7}$ Complement activation has been measured in vivo by crossed immunoelectrophoresis for $\mathrm{C} 3 \mathrm{c}^{,}{ }^{10}$ by an assay for $\mathrm{C} 3 \mathrm{~d}$ using radial immunodiffusion, ${ }^{911}$ and by radioimmunoassay of $\mathrm{C} 3 \mathrm{a}$ and $\mathrm{C} 5 \mathrm{a} .{ }^{12}$ Earlier workers detected varying amounts of complement activation in the bypass period. Recent work has thrown doubt on these findings since an assay of $\mathrm{C} \mathrm{d}^{9}{ }^{11}$ failed to confirm complement activation in the bypass period. The use of either corticosteroid ${ }^{4}{ }^{13}$ or pulsatile flow during cardiopulmonary bypass ${ }^{14} 15$ is controversial. 


\section{Methods}

Adult patients undergoing cardiopulmonary bypass were divided into three groups. Thirty four consecutive patients were selected by random number allocation for one of two groups, either control or treatment with intravenous methylprednisolone. Group 1 (17 patients) received the standard anaesthetic technique described below. Group 2 (17 patients) received in addition $30 \mathrm{mg} / \mathrm{kg}$ methylprednisolone during the anaesthetic induction and an additional dose of $30 \mathrm{mg} / \mathrm{kg}$ immediately before connection to the heart-lung machine. A further 10 consecutive patients formed group 3, who were studied after groups 1 and 2, did not receive methylprednisolone but underwent pulsatile perfusion flow from a Stockert device (Cobe-Stockert, Munchen, Germany), which achieves pulsatile flow by variable speed rotation of a roller pump applied externally to the circuit tubing. All patients received premedication with papaveretum and hyoscine, dose given according to weight. Anaesthetic induction was with thiopentone, phenoperidine, and pancuronium as appropriate. Careful note was made of all fluids added before, during, and after the perfusion period. An internal jugular cannula was inserted immediately after induction, and all samples for analysis were taken from this, except during the bypass period when blood was drawn from the venous side of the oxygenator. The heart-lung machine was primed with Hartmann's solution $(500 \mathrm{ml})$, polygeline $(500 \mathrm{ml})$, and dextrose $50 \%(150 \mathrm{ml})$. A bubble oxygenator (Bentley BOS 10) was used in all cases with a full flow of $2 \cdot 41 / \mathrm{m}^{2}$ body surface.

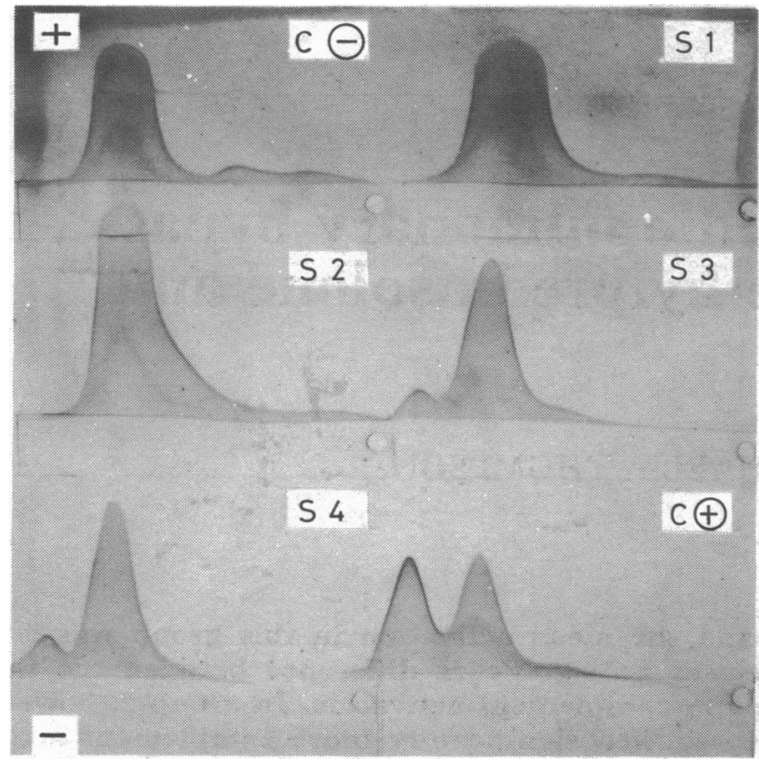

FIG 1-Example of crossed immunoelectrophoresis plate to demonstrate complement activation in a patient.

$\mathrm{C}=$ Negative control. $\mathrm{S1-4}=$ Patient's serial samples (see text). $\mathrm{C}+=$ Positive control

Blood samples were drawn off immediately after induction (sample 1), immediately before bypass after the administration of heparin $30 \mathrm{mg} / \mathrm{m}^{2}$ body surface (sample 2 ), after 30 minutes on cardiopulmonary bypass (sample 3), and a final sample after 60 minutes on cardiopulmonary bypass (sample 4). Blood was drawn into edetic acid and spun down within 30 minutes. The plasma was stored at $-70^{\circ} \mathrm{C}$ until analysis could be carried out. Plasma C3 and C4 concentrations were determined by radial immunodiffusion ${ }^{16}$ into buffered agarose gel containing specific antiserum. Quantification was carried out by comparison with dilutions of a normal human serum pool (12 people used; the standard being calibrated against the WHO standard for $\mathrm{C} 3$ and $\mathrm{C4}$ ) and the results expressed as a percentage of normal. The same standard was used throughout, and the changes in blood concentrations of $\mathrm{C} 3$ and $\mathrm{C} 4$ were studied, allowing the use of a serum pool standard for analysis of patients' plasma.

Measurement of C3 activation was carried out by a modification of the crossed immunoelectrophoresis method described by Versey. ${ }^{10}$ This technique entails electrophoretic separation of plasma protein in agarose gel followed by electrophoresis perpendicular to these into an antibody containing gel (fig 1). Our method consisted of a four hour separation at 12.5 volts/cm in the first dimension followed by a 17 hour separation at 4 volts $/ \mathrm{cm}$ in the second dimension. The antiserum was antihuman $\mathrm{C} 3 \mathrm{c}$ (Hoechst UK Limited) and was used at a concentration of $2 \cdot 3 \%$. Disodium edetic acid was used throughout the assay at a concentration of $0.01 \mathrm{mmol} / 1$ to prevent in vitro conversion of complement. ${ }^{17}$ Negative and positive controls were prepared, stored at $-70^{\circ} \mathrm{C}$, and included in all plates. Lipopolysaccaride (Difco Laboratories) was used to produce C3 conversion in normal serum, and a dose response curve was also set up. After running, the plates were washed, dried, and stained. The area enclosed by the individual precipitate is proportional to the amount of antigen. We measured the peak areas by planimetry ${ }^{18}$ and then calculated the conversion as follows: \% conversion $=($ area of converted C3 peak $($ C3c) $) /$ (area of converted + area of unconverted peak) $\times 100$. Stored blood was also examined to determine if activated complement was possibly transfused. The effect of aging on serum was studied by examining samples kept at room temperature, $4^{\circ} \mathrm{C}$, and $37^{\circ} \mathrm{C}$ for 24 hours.

The relatively large number of patients with $\mathrm{C} 3$ conversion results below the measurement limits of our method necessitated a means of ranking in such cases. We decided to use the peak height alone because this was obtainable in all but a very few cases. Although this is not satisfactory as a method of measuring $\mathrm{C} 3$ conversion it was found to correlate well with $\mathrm{C} 3$ conversions where available: conversion (3) level $v$ ratio (3) $\mathrm{p}<0.01$; conversion (4) level $v$ ratio (4) $\mathrm{p}<0.01$. The ratio values known as $R(3)$ and $R(4)$ were calculated as follows: ratio $R=$ (height of converted C3 peak)/(height of unconverted $\mathrm{C} 3$ peak) $\times 100$. The patients were then ranked according to their overall C3 conversion results, where available, or to the peak height ratio figures as defined above. Dilution of plasma due to mixing the pump prime was compensated for by consideration of change in packed cell volume in prebypass sample compared with a sample taken on bypass. The mean dilution going on to bypass was $1.5(\mathrm{SD}=0 \cdot 15)$.

To determine which of the many factors including age, sex, nature of operation, temperature of bypass, surgeon, ischaemic time, etc were related significantly to either $\mathrm{C} 3$ or $\mathrm{C} 4$ levels or $\mathrm{C} 3$ conversion, multiple correlation coefficients were determined using corrections for significance. ${ }^{19}$ Student's $t$ tests for parametric results and MannWhitney $U$ tests for non-parametric results were carried out where appropriate. In addition, analysis of frequencies was carried out by the $\chi^{2}$ test (table I).

TABLE I-Clinical details of 44 patients undergoing open heart surgery

\begin{tabular}{|c|c|c|c|}
\hline & $\begin{array}{l}\text { Control } \\
\text { group } \\
(\mathrm{n}=17)\end{array}$ & $\begin{array}{c}\text { Methylprednisolone } \\
\text { group } \\
(\mathbf{n}=17)\end{array}$ & $\begin{array}{l}\text { Pulsatile } \\
\text { group } \\
(\mathbf{n}=10)\end{array}$ \\
\hline Mean age (SD) & $51.06(10 \cdot 56)$ & $55 \cdot 24(10 \cdot 12)$ & $58.00(12.55)$ \\
\hline Age range & $38-71$ & 41-75 & 44-78 \\
\hline $\begin{array}{l}\text { Sex: } \\
\text { Men } \\
\text { Women }\end{array}$ & $\begin{array}{r}13 \\
4\end{array}$ & $\begin{array}{r}13 \\
4\end{array}$ & $\begin{array}{l}6 \\
4\end{array}$ \\
\hline Weight (kg) (SD) & $72.52(11.51)$ & $73.46(11.67)$ & $69.49(11.79)$ \\
\hline Weight range & $50 \cdot 6-94 \cdot 8$ & $48 \cdot 5-89 \cdot 0$ & $55 \cdot 0-91 \cdot 8$ \\
\hline $\begin{array}{l}\text { Surface area (SD): } \\
\text { Men (SD) } \\
\text { Women (SD) }\end{array}$ & $\begin{array}{l}1.83(0.19) \\
1.91(0.14) \\
1.60(0.09)\end{array}$ & $\begin{array}{l}1.81(0.21) \\
1.90(0.13) \\
1.51(0.14)\end{array}$ & $\begin{array}{l}1.77(0.19) \\
1.90(0.14) \\
1.58(0.03)\end{array}$ \\
\hline Packed cell volume (SD) & $27.56(3.40)$ & $25.94(3.47)$ & $28.3(6.05)$ \\
\hline $\begin{array}{l}\text { CABG: } \\
\text { Men } \\
\text { Women }\end{array}$ & 11 & ${ }_{11}^{11}$ & $\begin{array}{l}4 \\
1\end{array}$ \\
\hline $\begin{array}{l}\text { Valve: } \\
\text { Men } \\
\text { Women }\end{array}$ & $\begin{array}{l}2 \\
3\end{array}$ & $\begin{array}{l}2 \\
3\end{array}$ & $\begin{array}{l}2 \\
3\end{array}$ \\
\hline $\begin{array}{l}\text { Normothermic: } \\
\text { Men } \\
\text { Women }\end{array}$ & $\begin{array}{l}5 \\
4\end{array}$ & $\begin{array}{l}5 \\
2\end{array}$ & $\begin{array}{l}2 \\
1\end{array}$ \\
\hline $\begin{array}{l}\text { Hypothermic: } \\
\text { Men } \\
\text { Women }\end{array}$ & $\begin{array}{l}8 \\
0\end{array}$ & $\begin{array}{l}8 \\
2\end{array}$ & $\begin{array}{l}4 \\
3\end{array}$ \\
\hline $\begin{array}{l}\text { Ischaemic time (SD) } \\
\text { Total time (SD) }\end{array}$ & $\begin{array}{l}38.18(19.57) \\
69.59(20.31)\end{array}$ & $\begin{array}{l}39.59(21.00) \\
73.06(28.95)\end{array}$ & $\begin{array}{l}46.50(20.36) \\
76.40(33 \cdot 75)\end{array}$ \\
\hline
\end{tabular}

$\mathrm{CABG}=$ Coronary artery bypass graft

\section{Results}

COMPLEMENT CONCENTRATIONS (fig 2)

The C3 and C4 concentrations were above the lower limit of normal $(50 \%)$ throughout the operation, but $24(55 \%)$ of all patients showed 
a fall in $\mathrm{C} 3$ concentrations on bypass of more than $10 \%$, and analysis by Student's $t$ test showed a significant fall in $\mathrm{C} 3$ during the first 30 minutes on bypass for all groups $(p<0.001)$. Furthermore, the C 3 concentrations on bypass were significantly lower in groups 2 and 3 than in group 1 ( $\chi^{2}$ significant at 0.01 level). Analysis of correlation coefficients showed that more women than men in group 1 had lower concentrations of C3 on bypass and a greater decrease in C3 concentrations during the first 30 minutes of cardiopulmonary bypass $(\mathrm{p}<0.02)$.

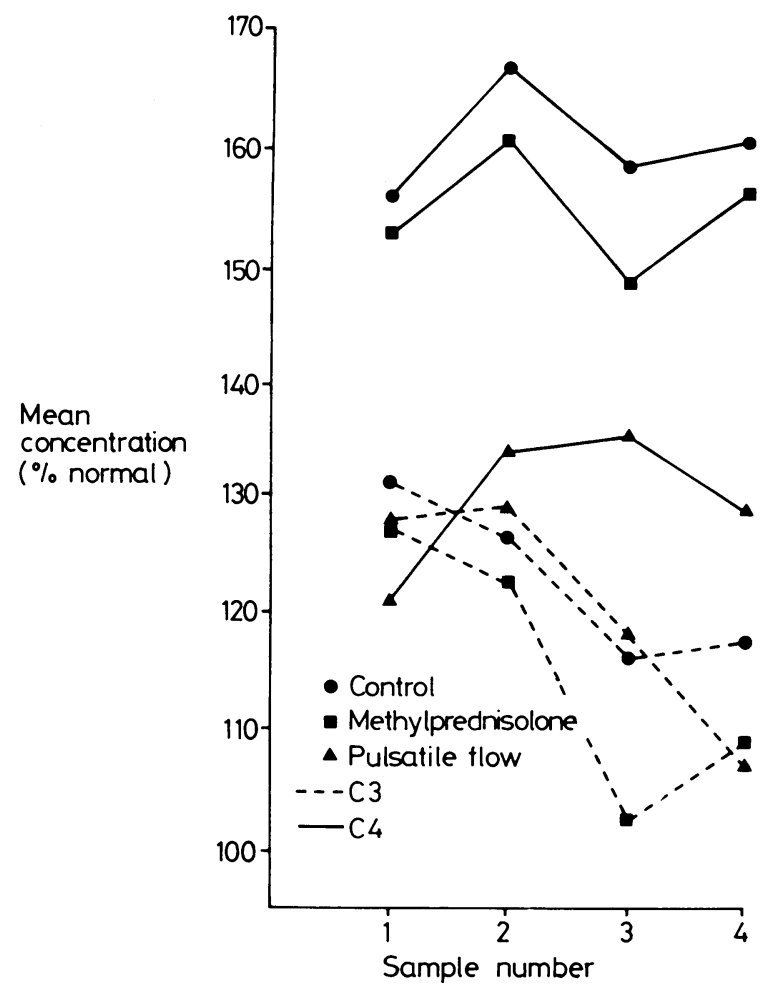

FIG 2-Mean $\mathrm{C} 3$ and $\mathrm{C} 4$ concentrations during anaesthesia and cardiopulmonary bypass (see text for timing of samples 1-4).

A total of $8(18 \%)$ of all patients showed a fall in C4 concentrations on bypass of more than $10 \%$. Analysis by Student's $t$ test showed a significant fall in $\mathrm{C} 4$ during the first 30 minutes on bypass for all groups $(p<0.05)$ and also $C 4$ concentrations showed a significant rise between induction and the start of cardiopulmonary bypass $(p<0.005)$. Further analysis by correlation coefficients showed that women in group 1 had a greater decrease in $\mathrm{C} 4$ concentrations than men during the first 30 minutes of cardiopulmonary bypass. Also in group 1 , the changes in $\mathrm{C4}$ concentrations during 30 to 60 minutes on bypass were not related to the type of operation. In group 3 (pulsatile flow), however, the concentrations of $\mathrm{C} 4$ after 30 minutes on bypass were higher in those having the valve than in those having the coronary artery bypass graft $(p<0.02)$.

\section{COMPLEMENT ACTIVATION (figs 1 and 3)}

Complement activation was not detected in the three units of stored blood given to patients during the bypass period. Complement activation was, however, detected in the aged serum at 24 hours. The levels were $23 \%$ at $37^{\circ} \mathrm{C},<4.5 \%$ at room temperature, and $<4.5 \%$ at $4^{\circ} \mathrm{C}$.

A total of $20(45 \%)$ of all patients showed measurable C3 activation in at least one sample on bypass. The percentage of patients affected in groups 2 or 3 was not significantly different from that in group 1. Examination of the crossed immunoelectrophoresis plates showed that the negative controls and the patients' samples before bypass were consistently negative. The coefficient of variation of the positive controls was $4.5 \%$, confirming the reliability of the method.

Table II shows the correlation of complement activation in samples taken during bypass (samples 3 and 4), carried out using the Mann-
Whitney $U$ test; further analysis using correlation coefficients agreed with these findings. Both sets of results showed that the difference in complement activation between valve and coronary artery bypass graft operations was particularly evident in group 1. It should, however, be noted that more women than men underwent valve operations and vice versa $(p<0.01)$ and also that one of the surgeons operating on the study groups performed more coronary artery bypass graft than valve operations $(p<0.01)$.

TABLE II-Correlations between degree of complement activation in different groups of patients undergoing open heart surgery

\begin{tabular}{|c|c|c|c|}
\hline Sample(s) & Group(s) & Test finding & p value* \\
\hline $\begin{array}{l}3 \text { and } 4 \\
3 \\
3 \\
3 \\
3 \\
3 \\
4\end{array}$ & $\begin{array}{l}2 \text { and } 3 \\
1,2 \text {, and } 3 \\
1,2 \text {, and } 3 \\
1,2 \text {, and } 3 \\
1 \\
2 \\
2\end{array}$ & $\begin{array}{l}v \text { group } 1 \\
\text { Valve }>\text { CABG } \\
\text { Women }>\text { men } \\
\text { Normothermic }>\text { hypothermic } \\
\text { Women }>\text { men } \\
\text { Women }>\text { men } \\
\text { Women }>\text { men }\end{array}$ & $\begin{aligned} & N S \\
&<0.01 \\
&<0.001 \\
& 0.054 \\
& 0.06 \\
&<0.03 \\
& 0.01\end{aligned}$ \\
\hline
\end{tabular}

As shown in table II and figure 3 there was a difference between men and women in the rapidity with which complement activation became evident during bypass. Although women already had activation in sample 3, men in general only developed significant activation in sample 4 (fig 3). The difference in complement activation in the normothermic and hypothermic groups (table II) was not biased by a difference in the proportion of cooled patients in the male and female groups. Finally, in contrast with the notable differences shown between women and men in group 2 , the pooled data (groups 1,2 , and 3 ) gave differences only for the first sample taken during bypass (sample $3)$.

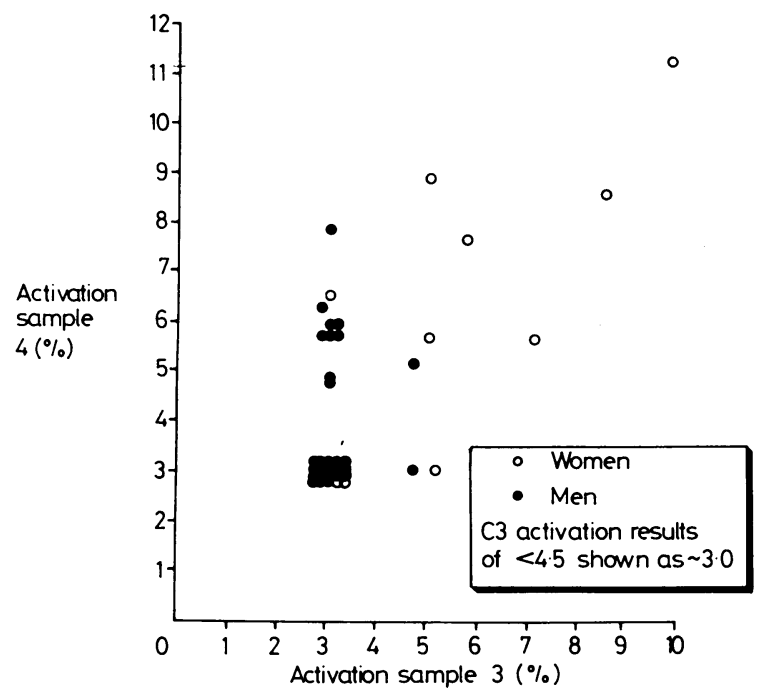

FIG 3-C3 activation in all groups of patients during bypass (samples 3 and 4). Women show activation in samples 3 and 4, while most men only developed evident activation in sample 4.

\section{Discussion}

The ability to detect in vivo complement activation is critically dependent on the laboratory technique used. We have shown that the method described by inhibiting in vitro complement activation and using the same control serum on all plates in the study is reliable (coefficient of variation $4.5 \%$ ). We used $0.01 \mathrm{mmol} / 1$ sodium edetic acid, and the control plates were consistently negative. A previous study used only $0.0025 \mathrm{mmol} / \mathrm{l}$ edetic acid, 6 but complement activation was shown in samples of stored blood and non-cardiac patient controls. C3 activation in stored blood has not been detected either by us or by other workers using the same technique. ${ }^{20}$ 
The value of determining concentrations of $\mathrm{C} 3$ and $\mathrm{C} 4$ as antigen has been debated by previous workers. C4 and to a lesser extent $\mathrm{C} 3$ are acute reactive proteins and sudden rises could be expected during the bypass procedure, which might tend to offset any depletion due to in vivo activation. A correction factor to take into account haemodilution from the pump prime must be applied, but it can be seen that true depletion occurred both in this study (fig 1 ) and in another. ${ }^{9}$

The role of corticosteroids has been little studied. No previous investigation has administered the drug in two doses to take account of the dilution shown by Thompson et al. ${ }^{21}$ In single dose studies in two patients, ${ }^{6}$ and in another in five patients, ${ }^{22}$ the authors concluded that steroids had no effect. Although we also could show no difference in activation in those patients who received the steroid compared with controls, the difference between men and women seen in the steroid group is of considerable interest. In the recent study by Boralessa and colleagues only men were examined. ${ }^{9}$ We cannot explain the apparent increase in complement activation seen in this subgroup but it is surprising, as steroids may suppress the immune response by their lysosome-stabilising activity. ${ }^{13} \mathrm{~A}$ previous study using a single dose of steroid found no difference in lung function. ${ }^{3}$ The role of pulsatile flow has not been elucidated here in relation to any complement related benefit. This study on a group of only 10 patients was sufficient for statistical analysis but requires extension before firm conclusions can be drawn.

It would be useful to relate change in complement activation to clinical outcome. Because of the many surgical factors an extremely large study would be necessary. In our study of 44 patients, three died in the perioperative period, all of whom had received methylprednisolone, but obviously no conclusion can be drawn. Our patients all underwent perfusion through a bubble oxygenator. This might be expected to cause both more trauma to the cellular elements of the blood and greater complement activation than a membrane oxygenator. Previous comparative studies ${ }^{22}$ have been too small to allow any conclusions to be derived.

\section{Conclusion}

We have confirmed that crossed immunoelectrophoresis is a reliable method of quantifying $\mathrm{C} 3$ activation in vivo provided that the technique described is followed. Complement activation of the order of $5 \%$ to $12 \%$ was detected in a significant number of patients during bypass and it is suggested that neither corticosteroids nor pulsatile flow effect this. The finding of increased levels of complement activation in women who received methylprednisolone might suggest caution with its use in this group of patients.

We thank Mr A K Yates, FRCS, and Mr P B Deverall, FRCS, for permission to study their patients; Mr R A Yewdall for carrying out the statistical analysis; and Miss A Whitmore for secretarial help.

\section{References}

1 Ratcliff NB, Young G, Hackel DB, Mikat E, Wilson JW. Pulmonary injury secondary to extracorporeal circulation: an ultrastructural study. $f$ Thorac Cardiovasc Surg 1973;65:425-32.

2 Parker DJ, Cantrell JW, Karp RB, Stroud RM, Digerness SB. Changes in serum complement and immunoglobulins following cardiopulmonary bypass. Surgery $1972 ; 71: 824-7$.

3 Enderby DH, Boylett A, Parker DJ. Methylprednisolone and lung function after cardiopulmonary bypass. Thorax 1979;34:720-5.

4 Thompson MA, Broadbent MP. Methylprednisolone prior to cardiopulmonary bypass. Anaesthesia 1980;35:345-53.

- Niazi Z, Flodin P, Joyce L, Smith J, Mauer H, Lillihei RC. Effects of glucocorticosteroids in patients undergoing coronary artery bypass surgery. Chest $1979 ; 76: 262-8$.

- Haslam PL, Townsend PJ, Branthwaite MA. Complement activation during cardiopulmonary bypass. Anaesthesia 1980;35:22-6.

${ }^{7}$ Kim Y, Michael AF, Kjellstrand CM, Mauer M. Complement activation by haemodialysis membranes. Dialysis and Transplantation $1982 ; 2$ : 4:265-70.

${ }^{8}$ Hammerschmidt DE, Stroneck DF, Bowers TK, et al. Complement activation and neutropenia occurring during cardiopulmonary bypass. f Thorac Cardiovasc Surg $1981 ; 81: 370-7$.

${ }^{9}$ Boralessa H, Shifferli JA, Zaimi F, Whitwan JG, Rees AJ. Perioperative changes in complement associated with cardiopulmonary bypass. $\mathrm{Br} \mathcal{F}$ Anaesth $1982 ; 54: 1047-52$

10 Versey JMB. Automated two-dimensional immunoelectrophoresis and its applications to the analysis of $\mathrm{C} 3$ and $\mathrm{C} 4$ in rheumatoid arthritis and systemic lupus erythematosus (SLE). Ann Clin Biochem 1973;10:100-6.

11 Perrin LH, Lambert PH, Miescher PA. Complement breakdown products in plasma from patients with systemic lupus erythematosus and patients with membranoproliferative or other glomerulonephritis. $\mathcal{f}$ Clin Invest $1975 ; 56: 165-76$

12 Chenoweth DE, Cooper SW, Hugli TE, Stewart RW, Blackstone EH, Kirklin JW. Complement activation during cardiopulmonary bypass: evidence for generation of $\mathrm{C} 3 \mathrm{a}$ and $\mathrm{C5a}$ anaphylotoxins. $N$ Engl F Med $1981 ; 304$ :497-503.

${ }^{13}$ Replogle RL, Gazzaniga AB, Gross RE. Use of corticosteroids bypass: possible lysosome stabilisation. Circulation $1966 ; 33-4$,suppl $1: 86-91$.

14 Kaplan JA, Craver JM. In: Kaplan JA, ed. Cardiac anaesthesia. New York: Grune and Stratton, 1979:464-6.

${ }^{15}$ Bregman D. Haemodynamic effects of pulsatile flow. In: Bolooki H, ed. Clinical applications of the intra-aortic balloon pump. Mt Kisco, NY: Futura, 1977:29-39.

${ }^{16}$ Mancini G, Carbonara AO, Heremans JF. Immunochemical qualification of antigens by single radial immunodiffusion. Immunochemistry 1965; 2:235-54.

${ }^{17}$ Hudson L, Hay FC. Practical immunology. Oxford: Blackwell Scientific Publications, 1976:139.

18 Axelson NH, Knoel J, Wekes B. Manual of quantitative immunoelectrophoresis. Scand $\mathcal{F}$ Immunol 1973;2,suppl 1:51.

19 Diem K, Lentner C, eds. Scientific tables: documenta Geigy. 6th ed. Macclesfield: Geigy Pharmaceuticals, 1970:63.

${ }^{20}$ Schifferli JA, Boralessa H, Whitwam JG, Rees AJ. Complement in CPD-stored blood. Vox Sang 1982;42:198-202.

21 Thompson MA, Broadbent MP, English J. Plasma levels of methylprednisolone following administration during cardiac surgery. Anaesthesia $1982 ; 37: 405-7$.

22 Jones HM, Matthews N, Vaughan RS, Stark JM. Cardiopulmonary bypass and complement activation: involvement of classical and alternative pathways. Anaesthesia $1982 ; 37: 629-33$.

(Accepted 15 August 1983)

ONE HUNDRED YEARS AGO Professor Haeckel's recent work on the lower forms of marine life in Ceylon contains an interesting passage on his experience as a diver amongst the coral reefs of that island. In order that he might thoroughly explore these remarkable formations, he learned to dive with his eyes open. The reality of this kind of exploit is less agreeable than the ideal. "The Oceanides, under whose protection these coral fairy bowers of the sea flourish, threaten the intruding mortal with a thousand perils. The Millepora, as well as the Medusae which float among them, burn him wherever they touch, like the most venomous nettles; the sting of the fish known as Synanceia is as painful and dangerous as that of the scorpion; numbers of crabs nip his tender flesh with their powerful claws; black sea-urchins (Diadema) thrust their foot-long spines, covered with fine prickles set the wrong way, into the sole of his foot, where they break off and remain, causing very serious wounds." Such were the Professor's experiences, as expressed in C Bell's English translation of $A$ Visit to Ceylon. Any attempt to detach a piece of coral of necessity involves the risk of severe injury to the hand. What is, however, most interesting to all who are likely to visit the tropics is that a bath in a coral reef may involve serious inconveniences not encountered by sea-bathers in high latitudes. (British Medical fournal $1883 ; \mathrm{i}: 1050$.)

\section{Correction}

Effects of pirbuterol and sodium nitroprusside on pulmonary haemodynamics in hypoxic cor pulmonale

An error occurred in this paper by Dr W MacNee and others (22 October, p 1169). The dose of intravenous sodium nitroprusside given to the patients was $1-5 \mu \mathrm{g} / \mathrm{kg}$ and not $1-5 \mathrm{mg} / \mathrm{kg}$. 